\title{
Melatonin Receptors Increase Momordica's Anticancer Effects Against PC-3 and HT-29
}

\section{Melatonin Reseptörleri PC-3 ve HT-29'a Karşı Momordica'nın Antikanser Etkilerini Artırır}

\author{
$₫$ Ali Taghizadehghalehjoughi', @Yesim Yeni' ${ }^{2}, \oplus$ Sidika Genc ${ }^{2}, \oplus$ David R Wallace $^{3}$, \\ $\triangle$ Ahmet Hacimuftuoglu' ${ }^{2}$, $\bigcirc$ Zeynep Cakir ${ }^{4}$ \\ 'Ataturk University, Faculty of Veterinary Medicine, Department of Pharmacology and Toxicology, Erzurum, Turkey \\ ${ }^{2}$ Ataturk University, Faculty of Medicine, Department of Medical Pharmacology, Erzurum, Turkey \\ ${ }^{3}$ Oklahoma State University Center for Health Sciences, School of Biomedical Sciences, Tulsa, Oklahoma, United States \\ ${ }^{4}$ Ataturk University, Faculty of Medicine, Department of Emergency Medicine, Erzurum, Turkey
}

\begin{abstract}
Aim: The aim of our study is to the evaluation of melatonin (MLT) and Momordica charantia (MC) combination on PC-3 and HT29 cancer lines and to address the question of where or not MLT increases MC antitumor effect in the PC-3 and HT-29 cancer lines.

Material and Method: The PC-3 and HT-29 cell lines were grown in a manufacturer-specified culture medium. Cisplatin, MLT, increasing concentrations of MC, $40 \mu \mathrm{g} / \mathrm{ml}$ MLT+increasing concentrations MC were applied to PC-3 and HT-29 cell lines for 72 hours. 3-(4,5-Dimethylthiazol-2-YI)-2,5-Diphenyltetrazolium Bromide (MTT) cell viability, Total Antioxidant Capacity (TAC), Total Oxidant Status (TOS), Cellular Migration (Wound Healing test), and Lactate Dehydrogenase (LDH) tests were done 72 hours after drug administration.

Results: The combination of MLT $40 \mu \mathrm{g} / \mathrm{ml}+\mathrm{MC} 100 \mu \mathrm{g} / \mathrm{ml}$ reduced cell viability in both PC-3 and HT-29 cells. Besides, TAC and TOS levels showed a correlation with $\mathrm{LDH}$ and MTT assays and were found to be statistically significant $(P<0.05)$. Also, it was observed in the migration test that the wound line widened in our combination groups from the 24th hours. However, it was observed that it only prevented migration at 72 nd hours in pure groups.

Conclusion: The combination of $40 \mu \mathrm{g} / \mathrm{ml}$ MLT with MC increased the antitumor effect compared to $M C$ alone and reduced the viability of cancer cells more effectively than MC alone. So, MLT+MC treatment combination can be a new resource of therapeutics.
\end{abstract}

Keywords: HT-29, LDH, Melatonin, Momordica, and PC-3

\section{Öz}

Amaç: Çalışmamızın amacı, PC-3 ve HT-29 kanser hatlarında melatonin (MLT) ve Momordica charantia (MC) kombinasyonunun değerlendirilmesi ve MLT'nin PC-3 ve HT-29 kanser hatlarında MC antitümör etkisini nerede artırdığı sorusunu ele almaktır

Gereç ve yöntem: PC-3 ve HT-29 hücre çizgileri, üreticinin belirlediği bir kültür ortamında büyütüldü. Sisplatin, MLT, artan MC konsantrasyonları, MLT $40 \mu \mathrm{g} / \mathrm{ml}+$ artan konsantrasyonlar MC, PC-3 ve HT-29 hücre hatlarına 72 saat süreyle uygulandı. 3- (4,5-Dimetiltiyazol2-YI) -2,5-Difeniltetrazolyum Bromür (MTT) hücre canlılı̆ı̆, Toplam Antioksidan Kapasitesi (TAC), Toplam Oksidan Durumu (TOS), Hücresel Göç (Yara İileştirme testi) ve Laktat Dehidrojenaz (LDH) testleri, ilaç uygulamasından 72 saat sonra yapıldı.

Bulgular: MLT $40 \mathrm{ug} / \mathrm{ml}+\mathrm{MC} 100 \mathrm{ug} / \mathrm{ml}$ kombinasyonu, hem PC-3 hem de HT-29 hücrelerinde hücre canlıı̆̆ını azalttı. Ayrıca TAC ve TOS seviyeleri LDH ve MTT testleri ile korelasyon gösterdi ve istatistiksel olarak anlamlı bulundu ( $<0.05)$. Ayrıca migrasyon testinde kombinasyon gruplarımızda 24. saatten itibaren yara hattının genişlediği gözlendi. Ancak saf gruplarda göçü sadece 72 . saatte engellediği görülmüştür.

Sonuç: $40 \mathrm{ug} / \mathrm{ml}$ MLT'nin MC ile kombinasyonu, tek başına MC'ye kıyasla antitümör etkisini arttırdı ve kanser hücrelerinin canlıı̆ını tek başına MC'den daha etkili bir şekilde azalttı. Dolayısıyla, MLT+MC tedavi kombinasyonu yeni bir terapötik kaynak olabilir.

Anahtar Sözcükler: HT-29, LDH, Melatonin, Momordica ve PC-3 


\section{INTRODUCTION}

Cancer is one of the most important public welfare problems on earth. Prostate (PC) and colorectal cancer (CRC) have the most important roles among malignant cancer types. CRC is the third most common types of cancer in men and women, causing approximately 1.4 million new cases and more than 0.5 million deaths worldwide. ${ }^{[1]}$ Located outside the prostate, $\mathrm{PC}$ is the second most common malignant tumor and is mostly seen in older men. ${ }^{[2]}$ Approximately one in six men will be diagnosed with $P C^{\left[{ }^{[3]}\right.}$ These two cancers have been associated with many risk factors, including smoking, alcohol consumption, dietary factors, lifestyle, ethnicity, and genetic changes. ${ }^{[4,5]}$ Early diagnosis, chemotherapy, surgical resection, radiotherapy, or targeted therapies can increase the survival of patients. ${ }^{[6,7]}$ Cisplatin has been especially interesting since it has shown anticancer activity in a variety of tumors, including those of the prostate and colon. However, the agents currently used for cancer treatment are usually cytotoxic and have serious side effects that can reduce the quality of life of cancer patients. ${ }^{[8]}$

Since ancient times, various plants have been used as medicines and vegetables worldwide. The combination of medicines and herbal uses has made Momordica types popular for thousands of years. Momordica, also known as bitter melon, bitter gourd, balsam pear, karela, and pare, is a member of the Cucurbitaceae family, which contains 800 species in 130 genera. [9] This plant has various biological activities like antioxidant, antiinflammatory, antidiabetic, antihyperglycemic, antibacterial, antiviral, anthelmintic, antiulcer, hepatoprotective, antifertility, antilipolytic, antimutagenic, and immunomodulation. ${ }^{[10]}$ Also, Momordica extracts and monomer components have shown strong anticancer activity against various tumors such as prostate, colon, lymphoid leukemia, lymphoma, melanoma, breast, skin, and pancreatic cancer. ${ }^{[11]}$ It has been proven in many studies that Momordica stops the G2/M cell cycle, stimulates autophagy and apoptosis, reducing the invasion and migration ability of cancer. Besides, it raises the question of whether it can be used in cancer treatment because of its low toxicity and non-cytotoxicity. ${ }^{[12]}$

Melatonin (N-acetyl-5-methoxideriptamine) is derived from the tryptophan and produced circadian rhythm. Melatonin (MLT) is synthesized in many organs and tissues, including the gastrointestinal, reproductive, and immune tract cells and skin. ${ }^{[13]}$ MLT is important in human pathology and physiology because of its role in the antioxidant scavenging system, anti-inflammation, immunomodulation, energy metabolism, and hematopoiesis. ${ }^{[14]}$ It has also been found MLT receptors play an oncostatic role in the PC and HT-29 through their interaction with MT1 and MT2. ${ }^{[15,16]}$ Due to its antioxidant properties, MLT has been shown to induce apoptosis in many studies and thus stop tumor creation. ${ }^{[17]}$

Although there are many separate studies in the literature related to MLT and MC, there is limited research about combined therapy and no data on the potential antitumor effects of MLT and MC. In this study, we purposed to search the antitumor effects of MLT and MC combination treatment in prostate (PC-3) and colorectal tumor (HT-29) cells for the first time. For this object, we planned the current study to consist of 13 distinct treatment groups. The antitumor study was done using MTT, LDH, TAC, TOS, and migration (Wound Healing test), and morphological observation for 72 hours (hrs).

\section{MATERIAL AND METHOD}

\section{Plant material, Chemicals, and Reagents}

MC was acquired from Sepe Natural Organic Products San.ve Tic.A.Ş. (Buca, Izmir, Turkey). MLT was acquired from Swanson Health Products (Fargo, ND, USA). All chemicals, phosphate-buffer solution (PBS), Dulbecco modified eagle medium (DMEM), fetal calf serum (FCS), trypsin-EDTA, antibiotic antimitotic solution (Penicillin/Streptomycin/Amphotericin B) (100X), and L glutamine was acquired from Sigma Aldrich (St. Louis, MO, USA). Cisplatin was obtained from Koçak Farma (Tekirdag, Turkey).

\section{Cell Cultures}

Prostate (PC-3) (ATCC ${ }^{\circledR}$ CRL-1435) and colon (HT-29) (ATCC $\left.{ }^{\circledR} \mathrm{HTB}-38\right)$ cancer cells were obtained from the department of the medical pharmacology department of Ataturk University (Erzurum, Turkey). Briefly, the cells were centrifuged at $1200 \mathrm{rpm}$ for $5 \mathrm{~min}$ at room temperature were suspended in a fresh medium and then aliquoted into 24-well plates at a density of 105 cells $/ \mathrm{ml}$ (DMEM, with FBS 10\%, and antibiotic (Penicillin, Streptomycin and Amphotericin $\mathrm{B} ; 1 \%$ ) and allowed to grow in a humidified incubator with $5 \% \mathrm{CO}_{2}, 95 \%$ moisture, at $37^{\circ} \mathrm{C}$. ${ }^{[18]}$

\section{Plant Administration}

After cells reached $85 \%$ confluency, the plant extracts were added to corresponding treatment wells. MC (10, 20, 40, 60, 80 and 100 $\mu \mathrm{g} / \mathrm{ml})$ alone or in combination $\mathrm{MC}(10,40,80,100 \mu \mathrm{g} / \mathrm{ml})$ and MLT $(40 \mu \mathrm{g} / \mathrm{ml})$ was added to designated treatment wells, and the plates were returned to the incubator for $72 \mathrm{hrs}$.

\section{MTT Assay}

At the end of the experiment (after 72 hrs of treatment), 10 $\mu \mathrm{L}$ of MTT solution is added to each well plate $(1 \mathrm{mM}$ final concentration). Then the plates were incubated for 4 hours at $37^{\circ} \mathrm{C}$ in a $\mathrm{CO}_{2}$ incubator. After 4 hours, $100 \mu \mathrm{L}$ of DMSO solution was added to each well to dissolve the formazan crystals. The density of the formazan crystals was read at a wavelength of $570 \mathrm{~nm}$ by the Multiskan ${ }^{\mathrm{TM}} \mathrm{GO}$ Microplate Spectrophotometer reader.

\section{TAC Assay}

TACcapacitywasinvestigatedbyusingtheexistingkit(manufactured by Rel Assay Diagnostics ${ }^{\circledR}$ Company, Gaziantep, Turkey). The test was done according to the manufacturer's procedure. To assess is made by calculating spectrophotometrically (Multiskan ${ }^{\mathrm{TM}} \mathrm{GO}$ Microplate Spectrophotometer reader). To assess the TAC status, $30 \mu \mathrm{l}$ of the sample was added to each well followed by $500 \mu \mathrm{l}$ of Reactive compound 1 (Buffer solution, Acetate Buffer), and the first absorbance was read at $660 \mathrm{~nm}$ (time 0). Then, $75 \mu \mathrm{l}$ of Reagent 2 (Prochromogen Solution, ABTS) was added to the wells and incubated for 10 minutes at room temperature. After the end of the time, the secondary absorbance value was read at $660 \mathrm{~nm}$. Distilled water Standard 1 (empty) was used, while Standard 2 
was used as the second point to calibrate the relationship of the absorbance density to the pro-oxidants present. TAC standards were determined in Trolox Equiv/mmol L-1.

\section{TOS Assay}

TOS was investigated by using the existing kit (manufactured by Rel Assay Diagnostics ${ }^{\circledR}$ Company, Gaziantep, Turkey). The test was done according to the manufacturer's procedure. To assess is made by calculating spectrophotometrically (Multiskan ${ }^{\mathrm{TM}} \mathrm{GO}$ Microplate Spectrophotometer reader). To assess the TOS standard, $75 \mu \mathrm{l}$ of the sample was added to each well followed by $500 \mu$ l of Reactive compound 1 (Buffer solution, $\mathrm{H}_{2} \mathrm{SO}_{4}$ ), and the first absorbance was read at $530 \mathrm{~nm}$ (time 0). Then, $25 \mu \mathrm{l}$ of Reagent 2 (Substrate Solution, $\mathrm{H}_{2} \mathrm{SO}_{4}$, Ferrus ion, O-dianisidine) was added to the wells and incubated for 10 minutes at room temperature. After the end of the time, the secondary absorbance value was read at $530 \mathrm{~nm}$. Distilled water Standard 1 (empty) was used, while Standard 2 was used as the second point to calibrate the relationship of the absorbance density to the pro-oxidants present. TOS standards were detected in $\mathrm{H}_{2} \mathrm{O}_{2}$ Equiv/mmol L-1. ${ }^{[19]}$

\section{LDH Assay}

LDH assay test was performed using a commercially available test kit from Cayman Chemical Co. Ltd, (Ann Arbor, MI, USA). Briefly, the cell culture medium was centrifuged at $400 \mathrm{~g}$ for $5 \mathrm{~min}$ at the room temperature $100 \mu \mathrm{l}$ of the supernatant was added to $100 \mu \mathrm{l}$ of the reaction solution (LDH Assay Buffer, LDH Substrate Mix) and incubated with gentle shaking on an orbital shaker for $30 \mathrm{~min}$ at room temperature. Finally, the absorbance was read at $490 \mathrm{~nm}$ wavelength. ${ }^{[20]}$

\section{Migration Test (Wound Healing Test)}

Cells were seeded in 24 -well plates and incubated $\left(37^{\circ} \mathrm{C}, 95 \%\right.$ air, $5 \% \mathrm{CO}_{2}$ ) for 3 days. Cultures at $\sim 80 \%$ confluence were scraped with a micropipette tip $(100 \mu \mathrm{l})$, rinsed with phosphate-buffered saline (PBS), and incubated with fresh media. At 24,48 , and 72 hrs intervals, all groups of the image were taken by Leica microscope.

\section{Statistically Analysis}

The statistical analysis was done using one-way analysis of variance (ANOVA)to assess treatment effects followed by Tukey's LSD for posthoc comparisons when appropriate using the SPSS 22.0 statistical software. $P<0.05$ was considered to be the statistical threshold for each analysis.

\section{RESULTS}

\section{MTT Assay}

The survival rate of cancer cells after $72 \mathrm{hrs}$ drug exposure was calculated by using the MTT test (Figure 1A-B). The vitality of the control group was defined as $100 \%$ and the other groups were rated accordingly. Our results show MLT $(40 \mu \mathrm{g} / \mathrm{ml})+\mathrm{MC}$ $(100 \mu \mathrm{g} / \mathrm{ml})$ combinations have the lowest rate of viability in both PC-3 and HT-29 cell lines in comparison to other treatments ( 63 and $66 \%$ respectively). The highest viability ratio among treatment groups in both PC-3 and HT-29 cells were seen in cisplatin $(2 \mu \mathrm{g} / \mathrm{ml})$ ( 86 and $81 \%$ respectively, $\mathrm{P}>0.05)$. Besides, the survival rate in pure MC $(10,20,40,60,80$ and 100 $\mu \mathrm{g} / \mathrm{ml}$ ) groups dose-dependently decrease from 81 to $74 \%$ in the PC-3 cell line and from 78 to $71 \%$ in the HT-29 respectively. According to our data, Combinations of MLT and MC kill both PC-3 and HT-29 cells more effectively than pure MC. Also, all $M L T+M C$ combination groups showed a statistical difference in comparison to the control group $(\mathrm{P}<0.05)$.
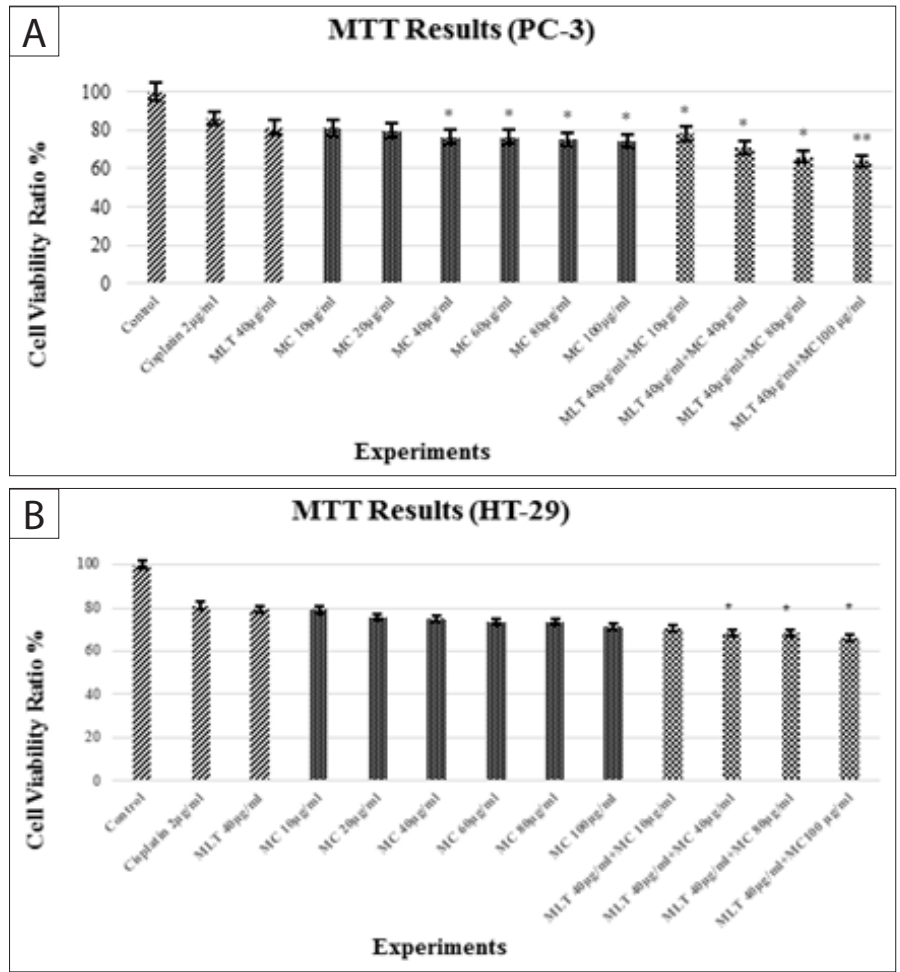

Figure 1A-B. In vitro viability ratio of MLT, MC or combination on PC-3 (A) and HT-29 (B) cells ( $n=6 /$ group).

*Significant differences at $\mathrm{P}<0.05$ comparedto control group; ** Significant differences at $\mathrm{P}<0.001$ compared to control group.

\section{TAC Assay}

We assessed the TAC assay based on Trolox Equiv/mmol L-1 (Figure 2A-B). According to this test, the TAC levels of the control group were 6.22 and 6.72 Trolox Equiv/mmol L- 1 in the PC-3 and HT-29, respectively. TAC levels of cisplatin $(2 \mu \mathrm{g} / \mathrm{ml})$ and MLT (40 $\mu \mathrm{g} / \mathrm{ml}$ ) were $6.09-5.80$ Trolox Equiv/mmol L- 1 in the PC-3 cell line, respectively. On the other hand, in the HT-29 cell line, TAC levels of cisplatin $(2 \mu \mathrm{g} / \mathrm{ml})$ and MLT $(40 \mu \mathrm{g} / \mathrm{ml})$ were $6.63-6.29$ Trolox Equiv/mmol L-1, respectively. Also, the antioxidant capacity decreased by increasing the dose from 10 to $100 \mu \mathrm{g} / \mathrm{ml}(2.51$ in the PC-3 and 2.11 in the HT-29 Trolox Equiv/mmol L-1). MLT (40 $\mu \mathrm{g} / \mathrm{ml})+\mathrm{MC}(100 \mu \mathrm{g} / \mathrm{ml})$ group was found statistically significant compared to the control group $(P<0.05)$. Furthermore, there no statistically significant difference between the other groups $(P>0.05)$.

\section{TOS Assay}

We assessed the TOS assay based on $\mathrm{H}_{2} \mathrm{O}_{2}$ Equiv/mmol L-1 (Figure 3A-B). As a result of this test, the oxidant levels of the PC-3 and 

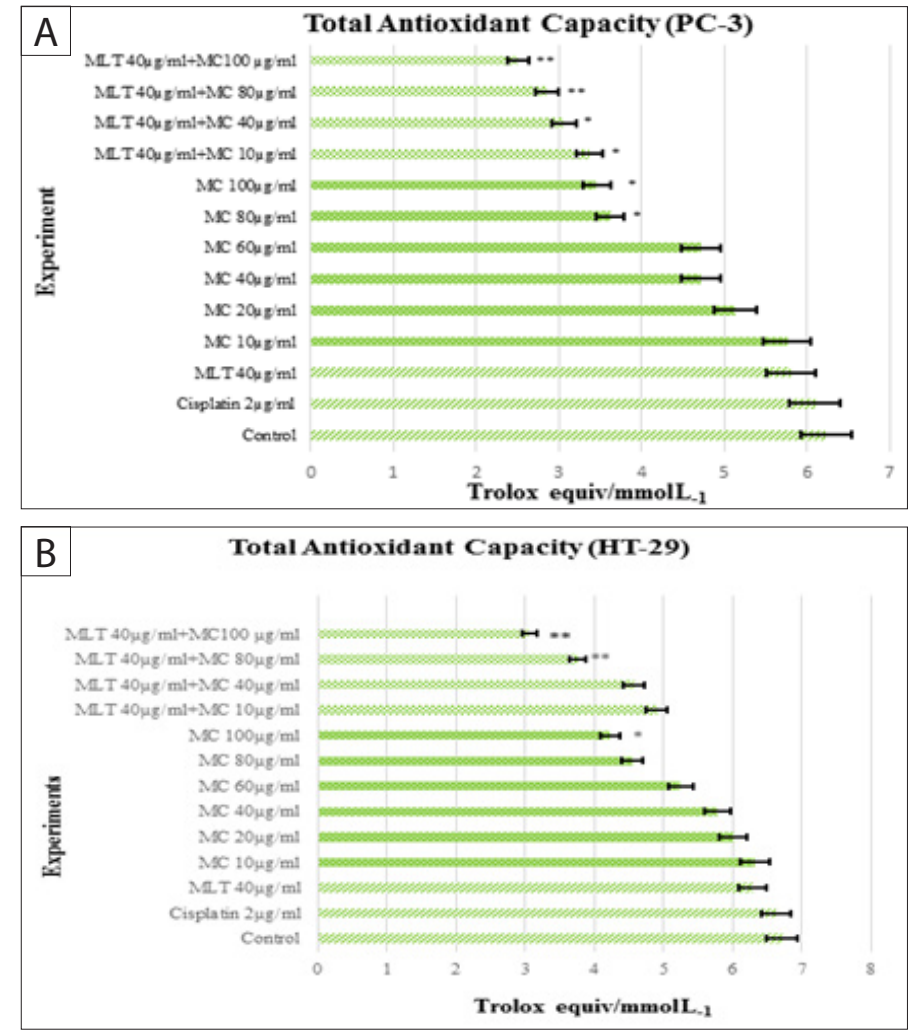

Figure 2A-B. In vitro TAC capacity of MLT, MC and combination of them on PC-3 (A) and HT-29 (B) cells ( $n=6 /$ group).

*Significant differences at $\mathrm{P}<0.05$ compared to control group; ${ }^{* *}$ Significant differences at $\mathrm{P}<0.001$ compared to control group.
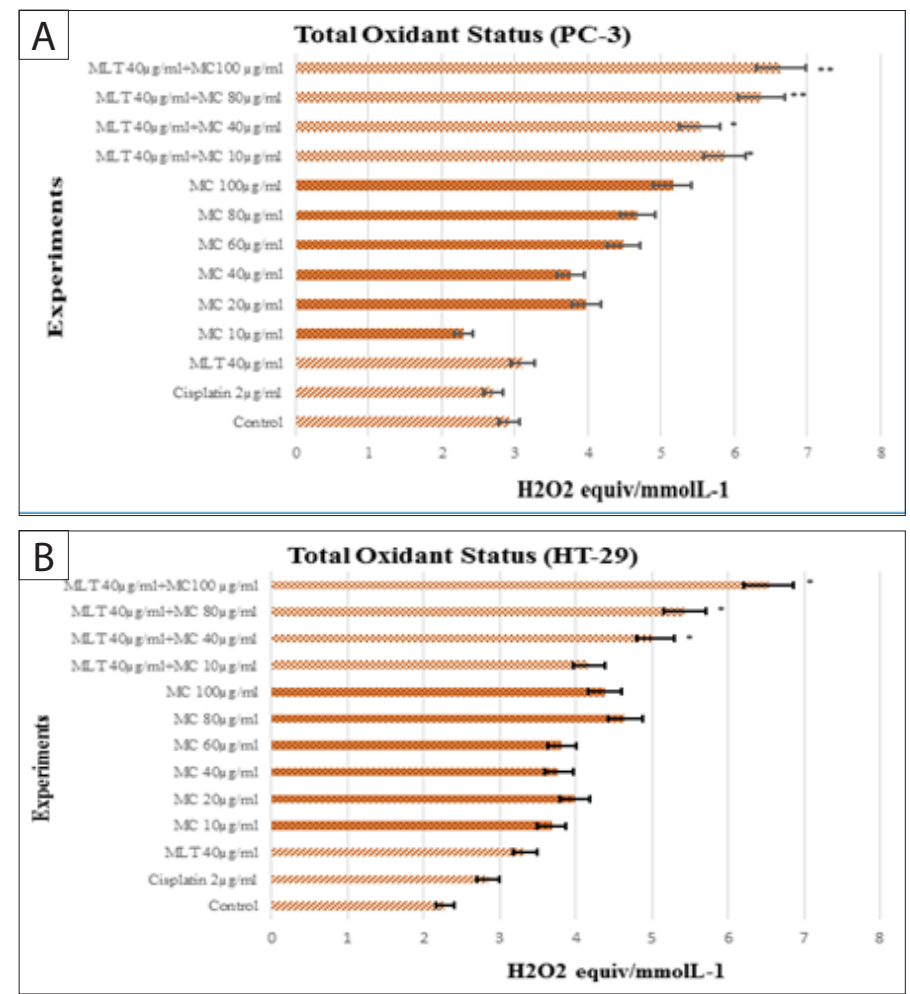

Figure 3A-B. In vitro TOS status of MLT, MC or combination on PC-3 (A) and HT-29 (B) cells ( $n=6 /$ group).

*Significant differences at $\mathrm{P}<0.05$ compared to control group; **Significant differences at $\mathrm{P}<0.001$ compared to control group.
HT-29 control groups were 2.92 and $2.28 \mathrm{H}_{2} \mathrm{O}_{2}$ Equiv/mmol L-1, respectively. The lowest oxidant ratio among the treatments was seen in cisplatin. On the other hand, oxidant status increased in pure MC groups and their combination with MLT both cell lines, respectively. According to these results, different combination of MLT $(40 \mu \mathrm{g} / \mathrm{ml})+\mathrm{MC}(100 \mu \mathrm{g} / \mathrm{ml})$ increased total oxidant ratio 6.64 and $6.53 \mathrm{H}_{2} \mathrm{O}_{2}$ Equiv/mmol L-1 in the PC-3 and HT-29, respectively $(\mathrm{P}<0.05)$.

\section{LDH Assay}

Damage to cell membranes is reflected as elevated LDH levels in the cell medium after the cells were exposed to MLT $(40 \mu \mathrm{g} /$ $\mathrm{ml}), \mathrm{MC}(10,20,40,60,80$ and $100 \mu \mathrm{g} / \mathrm{ml})$ or MLT+MC $(10,40,80$ and $100 \mu \mathrm{g} / \mathrm{ml}$ ) combinations for $72 \mathrm{~h}$. The LDH activity of the control group was defined as $100 \%$ and the other groups were rated accordingly. Our results show that the $\mathrm{MLT}(40 \mu \mathrm{g} / \mathrm{ml})+\mathrm{MC}$ $(100 \mu \mathrm{g} / \mathrm{ml})$ combination was most toxic as indicated by the greatest amount of LDH activity in the media from the PC-3 cell line in comparison to other treatments. When examining the HT-29 cell line, the combination of MLT $(40 \mu \mathrm{g} / \mathrm{ml})+\mathrm{MC}$ $(10,40,80$, and $100 \mu \mathrm{g} / \mathrm{ml})$ has the highest ratio of LDH activity compared to other treatments. Figures 4A-4B indicates that MLT+MC combinations induced cytotoxicity in PC-3 and HT-29 cell lines in both a time- and dose-dependent manner. Besides, all of the MLT+MC combination groups showed a statistical difference when compared to the control group $(P<0.001)$.
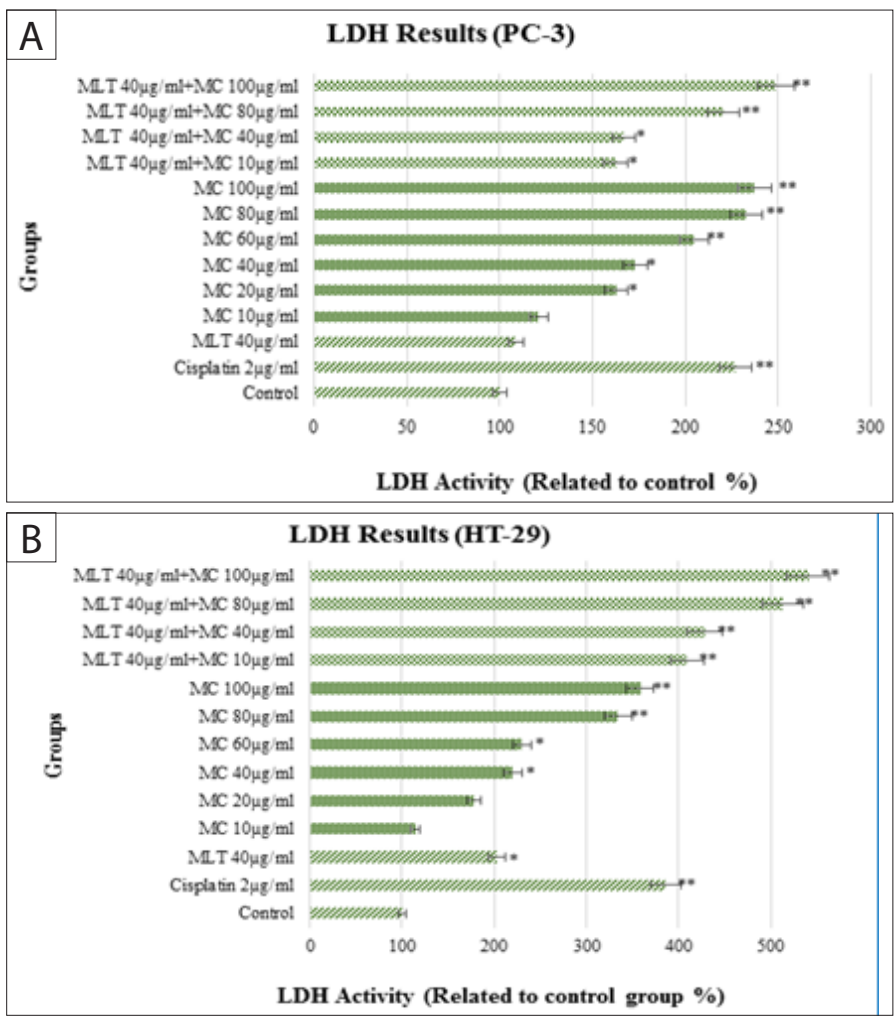

Figure 4A-B. In vitro LDH level of MLT, MC or combination on PC-3 (A) and HT-29 (B) cells ( $n=6 /$ group) values read spectrophotometrically at $490 \mathrm{~nm}$ in cell culture.

*Significant differences at $\mathrm{P}<0.05$ compared to control group; ${ }^{*}$ Significant differences at $\mathrm{P}<0.001$ compared to control group 


\section{Migration Test (Wound Healing Test)}

The wound area was assessed through three days of the PC-3 and HT-29 cell lines. Wounds opened in HT-29 and PC-3 cultures with the help of a 100-200 $\mu \mathrm{l}$ pipette tip are shown in figure Figure 5A-B. In the first $24 \mathrm{hrs}$, it was observed that the cells started to close the opened regions in the control group, while no change was detected in the other groups. When the $48^{\text {th }}$ hrs photos were examined, the control group progressed further and closed all wound areas. As the control group, the cisplatin group showed a large reduction in the wound area and the migrating cells bridged the wound site. Cell migration from the wound line to the middle of the wound was observed in the MLT $40 \mu \mathrm{g} / \mathrm{ml}$ and MC $10 \mu \mathrm{g} / \mathrm{ml}$ groups. However, the wound line was widened at the MC 20 to $100 \mu \mathrm{g} / \mathrm{ml}$ concentrations. Besides, cell deaths are seen at these concentrations. At the end of the $72^{\text {nd }}$ hrs, we observed that the wound lines were completely closed in the control and cisplatin groups. But in all treatment groups, including MLT $40 \mu \mathrm{g} / \mathrm{ml}$ and MC $10 \mu \mathrm{g} / \mathrm{ml}$, a high rate of cellular death was obvious. These cellular deaths are more apparent in the combination groups.

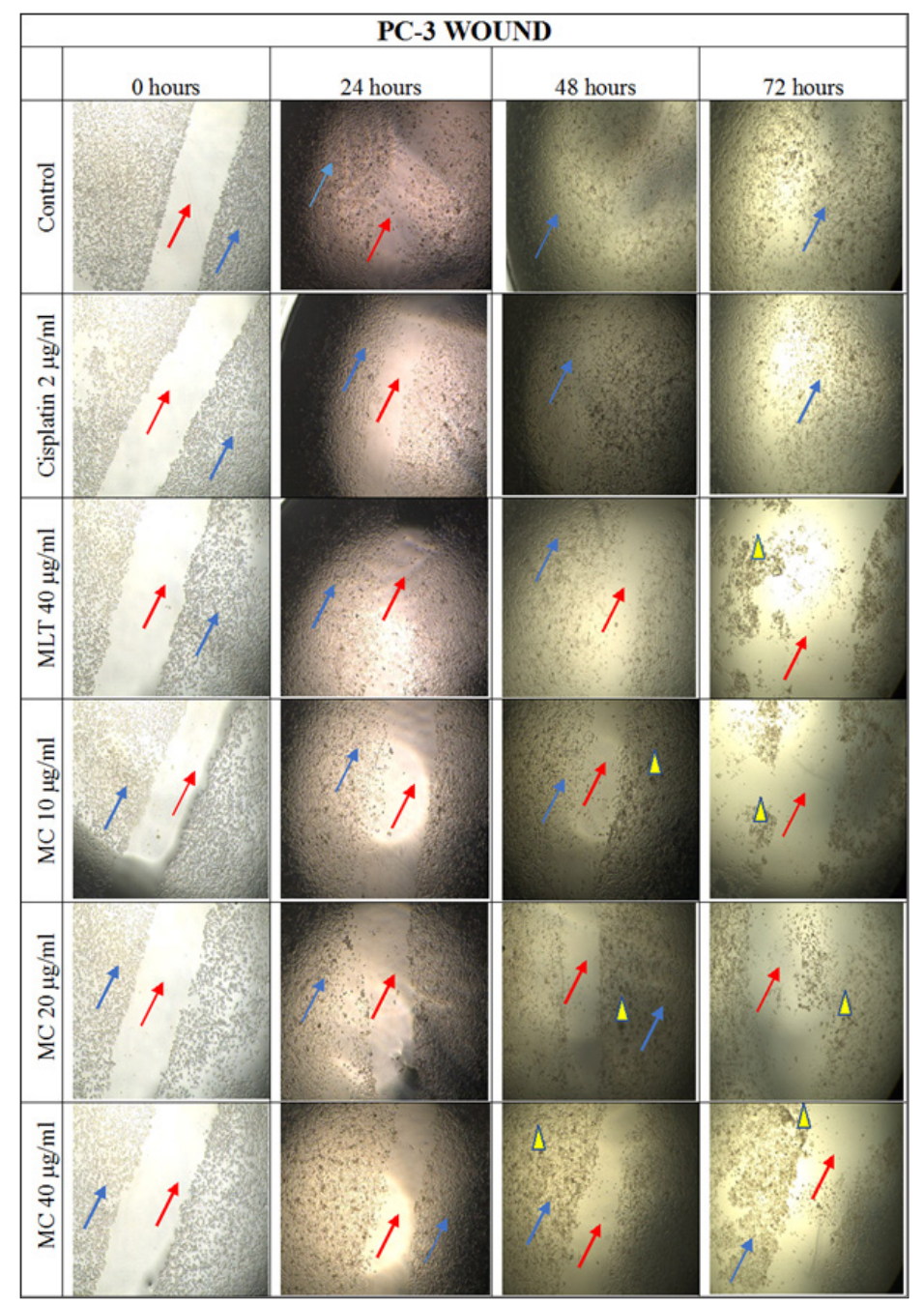

\section{DISCUSSION}

$\mathrm{CRC}$ and $\mathrm{PC}$ are malignant tumors with high incidence and chemotherapy is one of the most commonly used therapeutic methods for the treatment of these cancers. ${ }^{[2]]}$ Many studies suggest that bioactive natural compounds and their synthetic derivatives have an undeniable effect on cancer treatment procedures. ${ }^{[22]}$ Also, many anticancer studies found synergy between combinations of herbs and drugs. ${ }^{[23]}$ In this relation, our study showed that the combination of MLT+MC plays an important role as antioxidant and antitumor on PC-3 and HT29 cell lines.

MLT receptor expression has been demonstrated in many cancer types and activation of MT1 and MT2 receptors are suggested to induce antiproliferative and pro-differentiating effects. ${ }^{[24]}$ It has been shown that these receptors act through other regulatory effects by binding to nuclear receptors (RZR/ROR) or intracellular proteins belonging to the family of nuclear transcription factors. ${ }^{[25]}$ In light of these data, our study showed that the antitumor effect of MC was increased in PC-3 and HT-29 cell lines due to the antioxidant property of MLT.

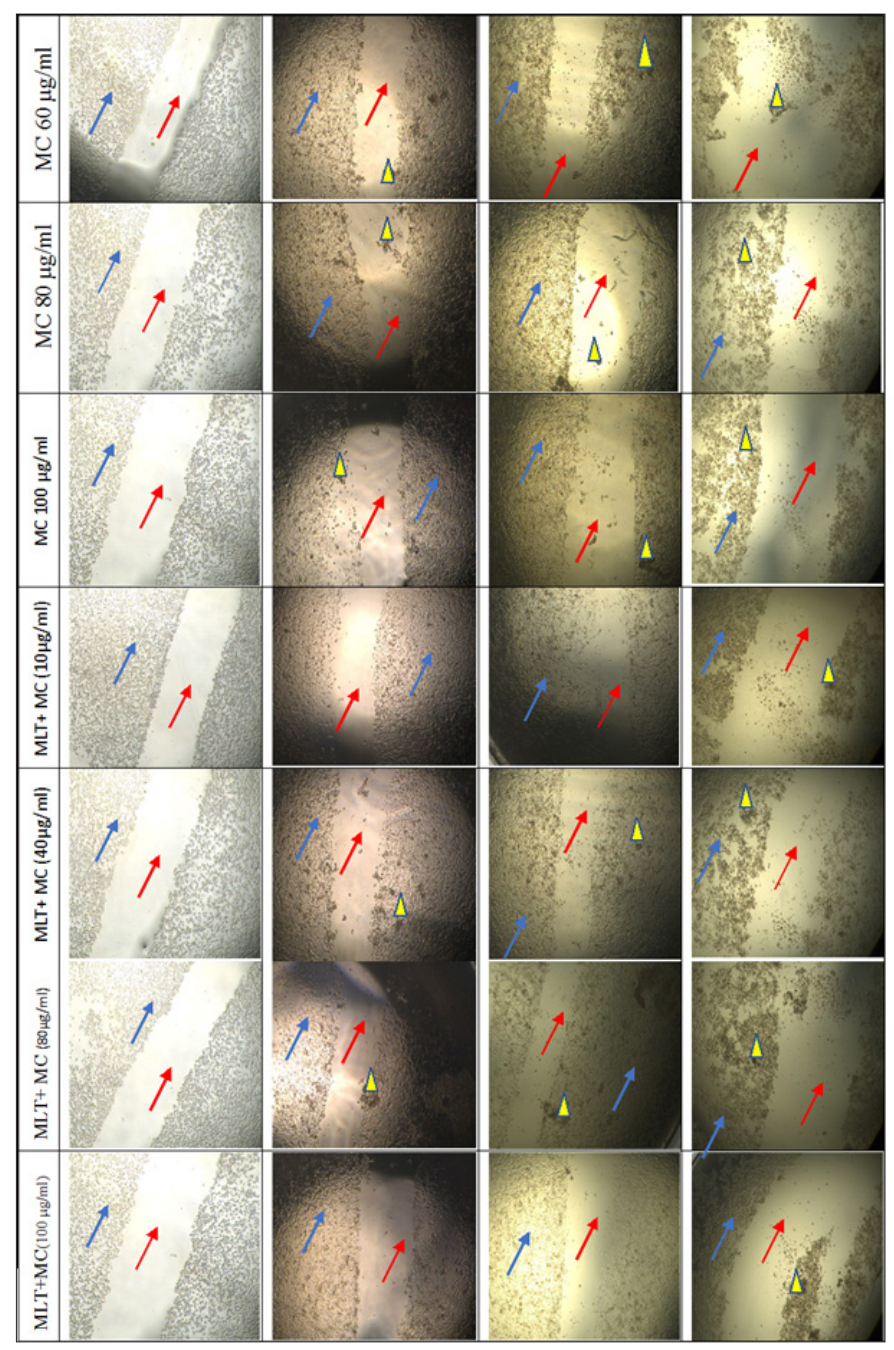

Figure 5A. Microscopic wound (migration test) view of each group after 24, 48 and 72-hrs (20x). Blue arrow: live cells, Red arrow: Empty space, Triangle: died cells 

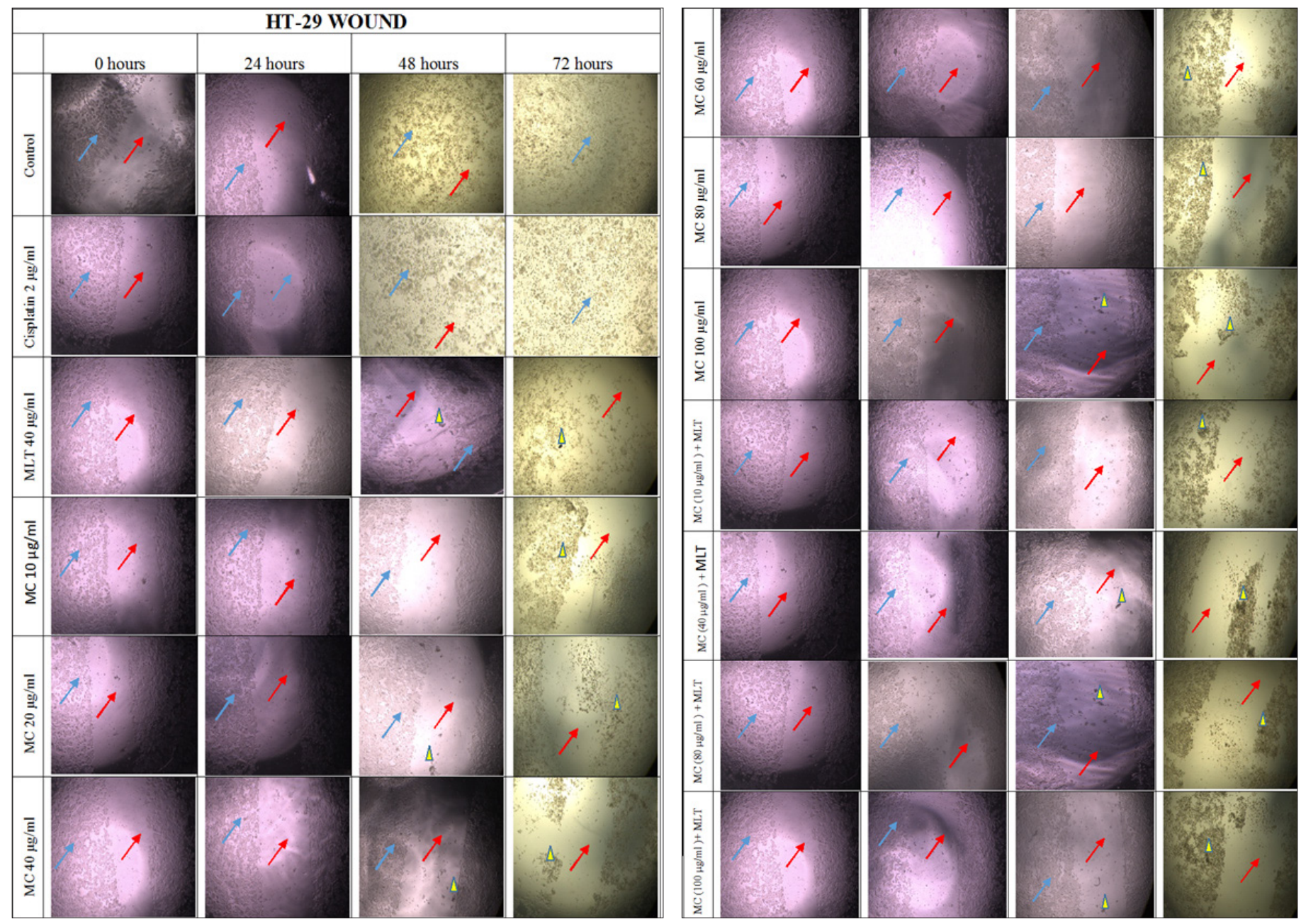

Figure 5B. Microscopic wound (migration test) view of each group after 24, 48 and 72-hrs (20×). Blue arrow: live cells, Red arrow: Empty space, Triangle: died cells

Calastretti et al. ${ }^{[14]}$ studied the oncostatin efficiency of UCM 1037, a MLT analog, in androgen-sensitive (LNCaP and 22Rv1) and -insensitive (PC3 and DU145) PC cells. In this study, cells were exposed to UCM 1037 at 10-4 M for 24, 48, and 72 hrs and demonstrated antiproliferative and cytotoxicity effects in LNCaP and 22Rv1 cells. However, androgen-insensitive cells like PC-3 and DU145 have shown low sensitivity to UCM 1037, indicating that MLT plays a more effective role in hormonedependent PC cells.

In a study was done by García-Navarro A et al. ${ }^{[26]}$ the antiproliferative effect of MLT on human colon cancer (HT29 cells) was investigated. After 48 hrs MLT incubation, they found that cell proliferation was reduced in a concentrationdependent and reached almost 100\% inhibition in 4 mM MLT. In addition, many studies have shown similar antiproliferative effects on human OAW-42, ME-180, ${ }^{[27]} \mathrm{HeLa}, \mathrm{HT}-29,{ }^{[28]}$ and CT$26^{[29]}$ cells after incubation with MLT.

In the present study, we evaluated the cytotoxic effects of MLT+MC combination on PC-3 and HT-29 cell lines with LDH and MTT assays. We demonstrated that the MLT+MC combination significantly decreased the viability of the cells on both cell lines in a dose-dependent manner $(P<0.05)$.
A parallel finding to our findings is provided by the work of Pitchakarn et al. ${ }^{[30]}$ who have found that MC treatment reduced cell growth of prostate cancer cell line concentrationdependently for 24 and $48 \mathrm{hrs}$. Dia et al. ${ }^{[3]]}$ showed that BG-4, a novel bioactive peptide isolated from $M C$, caused cytotoxicity in HCT-116 and HT-29 human colon cancer cells after 48 hours of treatment.Similarly, the findings of our study showed that the combination of MLT $(40 \mu \mathrm{g} / \mathrm{ml})+\mathrm{MC}(10,40,80$, and $100 \mu \mathrm{g} /$ $\mathrm{ml}$ ) decreased cell viability and caused further enlargement of the wound area.

The antioxidative/oxidative potential of MC+MLT combination evaluated with TAC and TOS assays. According to our results, MLT $(40 \mu \mathrm{g} / \mathrm{ml})+\mathrm{MC}(100 \mu \mathrm{g} / \mathrm{ml})$ group led to decreases in TAC level. On the other hand, TOS levels of MLT $(40 \mu \mathrm{g} / \mathrm{ml})+\mathrm{MC}(100$ $\mu \mathrm{g} / \mathrm{ml}$ ) treatment groups in both cell lines caused significant increases compared to the control value.

In our study, non-cytotoxic doses of MC, and MLT+MC combination dramatically reduced migration and invasion of human prostate and colon cancer cells. According to our data, the MLT antitumor effect increased when MC was added to both of the cell lines. Looking at the migration test, the combination group of MLT $(40 \mu \mathrm{g} / \mathrm{ml})+\mathrm{MC}(100 \mu \mathrm{g} / \mathrm{ml})$ has 
shown to be more effective than cisplatin and other groups in both cell lines.

The release of LDH in all cells is generally considered a marker of membrane permeability and damage. Popovich et al showed that a triterpenoid containing $M C$ seed extract did not increase lactate dehydrogenase release from cultured 3T3L1 murine fibroblast cells. However, in this study, MC extract reduced LDH activity after 48 and 72 hours of treatment, indicating that $M C$ triterpenoids were not effective on 3T3L1 cellular membranes to improve permeability. ${ }^{[32]}$ A study by conducted Lui et al. ${ }^{[33]}$ showed that other plant-derived extracts containing secondary metabolites affect 3T3-L1 cells, unlike both cultured colon carcinoma and hepatocarcinoma cells. According to our data, both PC-3 and HT-29 cell lines showed an increase in LDH activity due to MC concentration after 72 hrs of treatment.

\section{CONCLUSION}

Side effects and chemotherapeutic resistance to cisplatin are significant and pose major health concerns for the patient. Especially, irreversible DNA damage, neuropathic pain, and vital organ damage have led us to find better approaches to cancer treatment that will minimize or by-pass these significant side effects. In working towards this end of better therapeutics, we utilized the plant extract $\backslash(\mathrm{MC})$ and a hormone, MLT that has reported anticancer properties. The combination of MLT+MC shows promise to be a new anticancer agent for the treatment of colorectal or prostate cancer or adjuvant for the reduction of the side effects of chemotherapeutics. In our study, we report that the MC+MLT combination exerts inhibitory effects on the progression of cell lines PC-3 and HT-29 by inhibiting cell proliferation and viability and by suppressing cancer cell invasion. MLT and $M C$ together augmented the anticancer effects of each compound alone, not only by inducing oxidative stress, direct or indirect apoptosis but also by a direct effect on $\mathrm{M} 1$ and $\mathrm{M} 2$ receptors. By targeting both the MLT receptors and mitochondrial function, this would be an avenue for the development of new therapies for the treatment of prostate and colorectal cancer. Also, work is being done to investigate whether the combination of these agents along with cisplatin will permit the lowering of the cisplatin dose and the resulting reduction in cisplatin -mediated side effects.

\section{ETHICAL DECLARATIONS}

Ethiccal Issue: Not required as cell line is used and no animal or indal-derived studies.

Scientific Responsibility Statement: The authors declare that they are responsible for the article's scientific content including study design, data collection, analysis and interpretation, writing, some of the mainline, or all of the preparation and scientific review of the contents and approval of the final version of the article.
Animal and human rights statement: No animal or human studies were carried out by the authors of this article.

Referee Evaluation Process: Externally peer-reviewed.

Conflict of Interest Statement: The authors have no conflicts of interest to declare.

Financial Disclosure: The authors declared that this study has received no financial support.

Author Contributions: All of the authors declare that they have all participated in the design, execution, and analysis of the paper, and that they have approved the final version.

\section{REFERENCES}

1. Jemal, A., Global Cancer Statistics (vol 61, pg 69, 2011). Ca-a Cancer Journal for Clinicians, 2011.61(2): p. 134-134.

2. Knudsen, B.S. and V. Vasioukhin, Mechanisms of Prostate Cancer Initiation and Progression. Advances in Cancer Research, Vol 109, 2010. 109: p. 1-50.

3. Sandhu, G.S. and G.L. Andriole, Overdiagnosis of prostate cancer. J Natl Cancer Inst Monogr, 2012. 2012(45): p. 146-51.

4. Slattery, M.L., Diet, lifestyle, and colon cancer. Semin Gastrointest Dis, 2000. 11(3): p. 142-6.

5. Torre, L.A., et al., Global cancer statistics, 2012. CA Cancer J Clin, 2015. 65(2): p. 87-108.

6. Aklilu, M. and C. Eng, The current landscape of locally advanced rectal cancer. Nat Rev Clin Oncol, 2011. 8(11): p. 649-59.

7. Hanahan, D. and R.A. Weinberg, Hallmarks of cancer: the next generation. Cell, 2011. 144(5): p. 646-74.

8. Braun-Falco, M., et al., [Follicular drug reaction from cetuximab: a common side effect in the treatment of metastatic colon carcinoma]. Hautarzt, 2006. 57(8): p. 701-4.

9. Jia, S., et al., Recent Advances in Momordica charantia: Functional Components and Biological Activities. Int J Mol Sci, 2017. 18(12).

10. Raza, H., et al., Modulation of xenobiotic metabolism and oxidative stress in chronic streptozotocin-induced diabetic rats fed with Momordica charantia fruit extract. J Biochem Mol Toxicol, 2000. 14(3): p. 131-9.

11. Grover, J.K. and S.P. Yadav, Pharmacological actions and potential uses of Momordica charantia: a review. J Ethnopharmacol, 2004. 93(1): p. 123-32.

12. Yodkeeree, S., S. Garbisa, and P. Limtrakul, Tetrahydrocurcumin inhibits HT1080 cell migration and invasion via downregulation of MMPs and uPA. Acta Pharmacol Sin, 2008. 29(7): p. 853-60.

13. de Almeida Chuffa, L.G., et al., Mitochondrial functions and melatonin: a tour of the reproductive cancers. Cell Mol Life Sci, 2019. 76(5): p. 837-863.

14. Calastretti, A., et al., Melatonin Analogue Antiproliferative and Cytotoxic Effects on Human Prostate Cancer Cells. Int J Mol Sci, 2018. 19(5).

15. Eck-Enriquez, K., et al., Pathways through which a regimen of melatonin and retinoic acid induces apoptosis in MCF-7 human breast cancer cells. Breast Cancer Research and Treatment, 2000. 61(3): p. 229-239.

16. Winczyk, K., M. Pawlikowski, and M. Karasek, Melatonin and RZR/ROR receptor ligand CGP 52608 induce apoptosis in the murine colonic cancer. Journal of Pineal Research, 2001. 31(2): p. 179-182.

17. Toubi, E. and Y. Shoenfeld, Protective autoimmunity in cancer (Review). Oncology Reports, 2007. 17(1): p. 245-251.

18. Emsen, B., et al., The anti-cancer efficacies of diffractaic, lobaric, and usnic acid: In vitro inhibition of glioma. Journal of Cancer Research and Therapeutics, 2018. 14(5): p. 941-951.

19. Yeni, Y., et al., Antitumor Effect of Combination Momordica and Melatonin on Prostate Cancer Pc-3 Cell Line. Acta Physiologica, 2019. 227: p. 71-71.

20. Daneshmandi, S., B. Wegiel, and P. Seth, Blockade of Lactate Dehydrogenase-A (LDH-A) Improves Efficacy of Anti-Programmed Cell Death-1 (PD-1) Therapy in Melanoma. Cancers, 2019. 11(4).

21. Ehrke, M.J., Immunomodulation in cancer therapeutics. International Immunopharmacology, 2003. 3(8): p. 1105-1119. 
22. Rodriguez-Garcia, A., et al., Thioredoxin 1 modulates apoptosis induced by bioactive compounds in prostate cancer cells. Redox Biology, 2017. 12: p. 634-647.

23. Kanmani, P., et al., Production and purification of a novel exopolysaccharide from lactic acid bacterium Streptococcus phocae PI80 and its functional characteristics activity in vitro. Bioresource Technology, 2011. 102(7): $p$. 4827-4833.

24. Reiter, R.J., et al., Melatonin, a Full Service Anti-Cancer Agent: Inhibition of Initiation, Progression and Metastasis. International Journal of Molecular Sciences, 2017. 18(4).

25. Beckerandre, M., et al., Pineal-Gland Hormone Melatonin Binds and Activates an Orphan of the Nuclear Receptor Superfamily. Journal of Biological Chemistry, 1994. 269(46): p. 28531-28534.

26. Garcia-Navarro, A., et al., Cellular mechanisms involved in the melatonin inhibition of HT-29 human colon cancer cell proliferation in culture. Journal of Pineal Research, 2007. 43(2): p. 195-205.

27. Papazisis, K.T., et al., Effects of melatonin on proliferation of cancer cell lines. Journal of Pineal Research, 1998. 25(4): p. 211-218.

28. Pariente, R., et al., Participation of MT3 melatonin receptors in the synergistic effect of melatonin on cytotoxic and apoptotic actions evoked by chemotherapeutics. Cancer Chemotherapy and Pharmacology, 2017. 80(5): p. 985-998.

29. Farriol, M., et al., In vitro effects of melatonin on cell proliferation in a colon adenocarcinoma line. Journal of Applied Toxicology, 2000. 20(1): p. 21-24.

30. Pitchakarn, P., et al., Momordica charantia leaf extract suppresses rat prostate cancer progression in vitro and in vivo. Cancer Science, 2010. 101(10): p. 2234-2240.

31. Dia, V.P. and H.B. Krishnan, BG-4, a novel anticancer peptide from bitter gourd (Momordica charantia), promotes apoptosis in human colon cancer cells. Scientific Reports, 2016. 6.

32. Popovich, D.G., et al., Momordica charantia Seed Extract Reduces PreAdipocyte Viability, Affects Lactate Dehydrogenase Release, and Lipid Accumulation in 3T3-L1 Cells. Journal of Medicinal Food, 2011. 14(3): p. 201-208.

33. Liu, J., et al., Bog Bilberry (Vaccinium uliginosum L.) Extract Reduces Cultured Hep-G2, Caco-2, and 3T3-L1 Cell Viability, Affects Cell Cycle Progression, and Has Variable Effects on Membrane Permeability. Journal of Food Science, 2010. 75(3): p. H103-H107. 